\title{
Survey on Use of Language on Social Media: English versus Turkish in North Cyprus
}

\author{
Sarah Gambo \\ Faculty of Communication and Media Studies, Eastern Mediterranean University, TRN Cyprus \\ gamssarah@gmail.com
}

\section{I feoma Onyenegecha}

Department of Communication and Media Studies, Cyprus International University, TRN Cyprus Priscapaul556@gmail.com

\begin{abstract}
The Turkish Republic of Northern Cyprus is among the many countries which have long embraced the use of social media and social networking sites. The frequent access of and use of social networking platforms have been intensified by the presence of many institutions of learning and the increasing number of foreign students and tourists from across various countries of the world. The Northern Cypriot locals are not left out in the social media activities. The common networking sites frequently used in the setting include but not limited to Facebook, e-mail and twitter. Northern Cyprus is clearly multilingual but three languages seem to be common in communication: Turkish, English and Arabic. However, on the social media, broadcast messages, adverts and bulk sms from service providers are predominant in either English or Turkish. The methodology will be quantitative through survey. The research will compare the use of English and Turkish languages on social media in north Cyprus to determine which is more frequently used and more accessible to social media users. The possible findings would be that English and Turkish are in a competitive situation.
\end{abstract}

Keywords: Survey, Language, Social Media, English, Turkish.

\subsection{Introduction}

Language is arguably one of the greatest assets of humanity. The interactive, expressive and integrative functions of language above all, places language and language use at a high esteemed value. Language use is continuous irrespective of ethno-cultural settings such that nature provides virtually everyone a platform to communicate and be communicated to in the place of a family, peer group, ethnic group, education environment, place of worship, social platforms amongst others. However, over the years, some languages have assumed a superior position while others have become suppressed and others still in the verge of extinction.

The superiority position in this case is in terms of usage, global recognition and international acceptance in global education, business, and economic market. Apparently, the world powers are advantaged in this situation in that the more powerful a country was, the higher the probability of conquering smaller nations and consequently colonizing them and imposing their own language on these colonies.

The place of English language in global community cannot be overestimated; it is the language of international business, the language of world leadership summits, the language of most academic conferences, workshops and seminars such that irrespective 
of the official language of the host countries, the language of activity would likely be in English.

In any case, the Turkish republic of Northern Cyprus constituted a mono-lingual community of Turkish speaking locals before the birth of universities which recently attract international students and foreigners of diverse language speakers. These universities discharge their classroom duties in either English or Turkish language as the case may be. In some courses, the language of instruction is purely Turkish whereby learners are mostly of Turkish speaking backgrounds or others who have to undergo intensive Turkish courses to enable them fully admitted to study the courses whereas others are in English wherein international students of English speaking backgrounds constitute the learners or others of non- English speaking backgrounds are required to take English deficiency courses to enable them fully accepted to study their course of interest.

Meanwhile, some of these foreigners possess among them, their own native languages which is neither English nor Turkish. Hence, it becomes clear that the current language situation of North Cyprus is no longer the original mono-lingual but now multi-lingual. The social- media which is widely used in North Cyprus by mostly teenagers and adults of various age groups is a very important aspect of their day to day activities whether students, foreigners or natives.

The role and use of social media could either be interesting or frustrating based on the language with which a message is sent across and the language understood by the social media user. Although there may be a provision to translate into either of the two languages for the benefit of all, the originality of the message cannot be compared. Worthy of comparison therefore is the use of these two languages on social media in terms of number of convenient users, as well as number of people who depend on translations to understand a message passed across in either of the two languages on social media.

\subsection{Social Media}

Social Media going by its name implies the aspect of communication that changes the phase of communication from what it used to be to a new form of global communication. Meanwhile different scholars see social media as refer to be an avenue that permits individuals to contribute openly or in semi-public outline disruption in a closed system, with a group of others which they relate by networking extended by others within the system(boyd \& Ellison, 2007). This implies how it is opened to the public whose views are widely accepted and it can be used for groups who want to share their ideas.

In related development, social media is said to be largely accepted as what took Radio and Television about 38 and 14 years to achieve about 50 million users, while the internet took only about 4 years. But the Facebook took only 1 year to hit a limelight of above 200 million users or participants (Awake, 2012). Courtney (2007), observed that the social media is capable of building knowledge, create it and also enable the users to participate, emphasizing that its openness enable the users to have knowledge which permit their local views on the social network space.

According to Ohiagu \& Okorie, (2014), social media has been rooted in our everyday lives that people's impression, understanding and construction of meanings and general views of lives reflect it. The social media is able to utilize this platform. There is no part of human activity that is not touched with the social media, which has even gone to an aspect of playing games, shopping and even listening tour news online. More also budgeting and the banking sector have gone online, hence social media is a necessary evil, linking the whole world together in a twinkle of an eye. This is conquer by what 
(Oghenetega \& Ejedafiru (2014), said that life is made a little bit easier academically, politically, socially for as many that are linked up to social media hence people stress less.

Contrary some scholars are of the opinion that social media affects people negatively, as the scholars below explain how the social media have affected performances in school, Ebere \& Oghenetega, (2014)66.33\% were negatively affected with just positive impact of $33.67 \%$, while other scholars see it from perspective of addiction that, among the youths, to be specific in Nigeria; it is believe that social networks have come to change the way people associate before stressing that the manner in which the brain process information before has been tempered with (Naurt, 2007).

\section{Languages in North Cyprus}

Historically, Cyprus as a whole was a British colony for many years. In fact, it gained independence from Britain in 1960. "The history of the island of Cyprus since the negotiated accession to independence of the republic in 1960 has been a sad and complex sequence of events"Necatigil, (1993)A war ensued in 1974and caused a division which resulted in the Greek-majority south Cyprus and Turkish- minority North Cyprus. The Turkish-minority Cyprus was declared a republic in 1983 giving birth to the name "Turkish republic of North Cyprus" about thirty four years ago. The linguistic implication of the history of Northern Cyprus is that English long existed as the language of the first colonial masters before the current existence of Turkish language. Turkish language is today the official languageof North Cyprus while English is considered the second language. It is pertinent therefore to consider what scholars posit about language. According to kanga (1996,) Language is seen as a vital point that aid in determining one's self-wish. For Cogo (2008), it is something that is everywhere and around. In a related development, Leech \& Short, (2007), affirm that language is used for different purposes such as requesting, persuading, emphasizing, and also for reassuring of issues. With the history of North Cyprus, it is understandable for both English and Turkish to be in use in the territory but it has today become a multilingual society as a result of the presence of variety of schoolers and tourists from different nationalities.

\section{An overview of English Language in TRNC}

Crystal (1997) considers English as pertinent in any community stressing that if there is need for development, in that setting it can be applied by all. Globally at international level, the position of the English language, cannot be replaced according to (Mauranen and Rauta 2009, p1) submission, that the role English plays is intercultural and international. Emphasizing on this, the world generally is constantly altering as a result of technology, this has also affected languages (Cogo 2008) since the technology are mostly originally in English language. In addition, Smokotin, Alekeseyenko, \& Petrova (2014), consider the aspect which English has been encouraged by some others especially in academics for international publication and so the need for it has been iterated for usage by all regarding it as a language for must do activities and functions.

\section{Overview of Turkish Language}

Turkish language on its own equally has surprising significance and enormous relevance. According to Turner (2015), speaking about Turkish language, he says"it is full of idiosyncratic idioms and expressions from across the middle-east. The language incorporates aspects of Farsi, which is the language spoken in Iran, a lot Arabic, quite a few French word..." according to another source, Turkish is a significant language first because of the sheer number of people who speak it. 75 million people speak Turkish as their first language, making it one of the globe's 15 most widely spoken first languages. There are other communities of speakers in Balkans and Caucasus and several very large Turkish immigrant communities in Western Europe (Turkish is the second most 
widely spoken language in Germany, for example). Another 15 million people speak Turkish as a second language,

\subsection{Methods and Procedure}

From the 150 copies of questionnaires that were administered only 147 copies were properly filled and returned. This shows that the response rate is high at $98 \%$. The target sample for this study is people of social media using age resident in North Cyprus as citizens and foreigners which encompass various academic levels. The research is conducted within the Northern Cyprus which is majorly an academic environment where people from different nationalities are represented thereby ascertaining reliability and validity of the study.

Out of 147 respondents, $(n=70) 47.7 \%$ are between the age $18-25,(n=49)$ made up of $33.3 \%$ in age bracket $26-33$, while $(n=20)$ constituting $13.6 \%$ in age bracket $34-42$, and from 43 and above $(n=8) 5.4 \%$.

On gender, males constitute $(n=20) 63.3 \%$ while females constitute $(n=34) 36.7 \%$. This shows that there are more male social media users in north Cyprus than their female counterparts. On educational level, $(n=6) 4 \%$ are high school students, $(n=69) 46.9 \%$ are bachelor's degree students, $(n=47) 32.0 \%$ are master's degree students while $(n=25) 17.0 \%$ are doctorate students.

Table 1 below shows the demographic information of respondents as interpreted above.

\subsection{Demographic I nformation of respondents}

Table 1: demographic information of respondents

\begin{tabular}{|l|l|l|l|l|}
\hline Age & Frequency & Percentage & Valid percent & Cumulative \\
\hline $18-25$ & 70 & 47.6 & 47.6 & 47.6 \\
\hline $26-33$ & 49 & 33.3 & 33.3 & 81.0 \\
\hline $34-42$ & 20 & 13.6 & 13.6 & 94.6 \\
\hline 43 and above & 8 & 5.4 & 5.4 & 100.0 \\
\hline Total & 147 & 100.0 & 100.0 & \\
\hline & & & & \\
\hline Gender & & & & \\
\hline MALE & 93 & 63.3 & 63.3 & 63.3 \\
\hline FEMALE & 54 & 36.7 & 36.7 & 100.0 \\
\hline Total & 147 & 100.0 & 100.0 & \\
\hline & & & & \\
\hline level of Education & & & & \\
\hline HIGH SCHOOL & 6 & 4.1 & 4.1 & 4.1 \\
\hline BACHELOR & 69 & 46.9 & 46.9 & 51.0 \\
\hline MASTER & 47 & 32.0 & 32.0 & 83.0 \\
\hline DOCTORATE & 25 & 17.0 & 17.0 & 100.0 \\
\hline Total & 147 & 100.0 & 100.0 & \\
\hline Source Field Survey 2017 & & & \\
\hline
\end{tabular}

Source: Field Survey 2017.

On background information, on who are indigenes of North Cyprus, $(n=23)$ with $15.6 \%$ while non-indigenes are $(n=124) 84.4 \%$. On their use of social media for communication respondents are as follow for those who said they use it $(n=144) 98 \%$ where as those who said they don't use the social media constitute (3) $2.0 \%$ and on the issue of language mostly used on social media, the English language is at $(n=127) 86.4 \%$ while Turkish users are at $(n=20) 13.6 \%$. In aspect of translation, since the two languages have translations medium on social media, those who depend on translation to 
understand English are $(n=35)$ with $23.8 \%$, while those who don't depend on it are $(n=112) 76.2 \%$.

\subsection{Background I nformation}

TABLE 2

\begin{tabular}{|c|c|c|c|c|}
\hline $\begin{array}{l}\text { Are you from } \\
\text { Northern Cyprus? }\end{array}$ & Frequency & Percent & Valid Percent & Cumulative Percent \\
\hline Yes & 23 & 15.6 & 15.6 & 15.6 \\
\hline No & 124 & 84.4 & 84.4 & 100.0 \\
\hline Total & 147 & 100.0 & 100.0 & \\
\hline $\begin{array}{l}\text { Do you use social } \\
\text { media for } \\
\text { communication }\end{array}$ & Frequency & Percent & Valid Percent & Cumulative Percent \\
\hline Yes & 144 & 980 & 980 & 980 \\
\hline No & 3 & 2.0 & 2.0 & 100.0 \\
\hline Total & 147 & 100.0 & 100.0 & \\
\hline $\begin{array}{l}\text { How many hours to } \\
\text { you spend on social } \\
\text { media? }\end{array}$ & Frequency & Percent & Valid Percent & Cumulative Percent \\
\hline At most 30 minutes & 7 & 4.8 & 4.8 & 4.8 \\
\hline $\begin{array}{l}\text { Between } 30 \mathrm{~min} \text { to } 1 \\
\text { hour }\end{array}$ & 24 & 16.3 & 16.3 & 21.1 \\
\hline $\begin{array}{l}\text { Between } 1 \text { hour to } 3 \\
\text { hours }\end{array}$ & 50 & 34.0 & 34.0 & 55.1 \\
\hline $\begin{array}{l}\text { Between } 3 \text { hours to } \\
\text { 5hours }\end{array}$ & 40 & 27.2 & 27.2 & 82.3 \\
\hline More than 5 hours & 26 & 17.7 & 17.7 & 100.0 \\
\hline Total & 147 & 100.0 & 100.0 & \\
\hline $\begin{array}{l}\text { Do you use Turkish } \\
\text { for written } \\
\text { communication on } \\
\text { social media? }\end{array}$ & Frequency & Percent & Valid Percent & Cumulative Percent \\
\hline Yes & 52 & 35.4 & 35.4 & 35.4 \\
\hline No & 95 & 64.6 & 64.6 & 100.0 \\
\hline Total & 147 & 100.0 & 100.0 & \\
\hline $\begin{array}{l}\text { Do you understand } \\
\text { Turkish messages, } \\
\text { adverts or news on } \\
\text { social media? }\end{array}$ & Frequency & Percent & Valid Percent & Cumulative Percent \\
\hline YES & 49 & 33.3 & 33.3 & 33.3 \\
\hline $\mathrm{NO}$ & 98 & 66.7 & 66.7 & 100.0 \\
\hline Total & 147 & 100.0 & 100.0 & \\
\hline
\end{tabular}




\begin{tabular}{|l|l|l|l|l|}
\hline $\begin{array}{l}\text { Do you understand } \\
\text { and respond to } \\
\text { spoken Turkish on } \\
\text { social media? }\end{array}$ & Frequency & Percent & Valid Percent & Cumulative Percent \\
\hline YES & 52 & 35.4 & 35.4 & 35.4 \\
\hline NO & 95 & 64.6 & 64.6 & 100.0 \\
\hline Total & 147 & 100.0 & 100.0 & \\
\hline $\begin{array}{l}\text { Which of these two } \\
\text { languages do you } \\
\text { commonly use on } \\
\text { social media? }\end{array}$ & Frequency & Percent & Valid Percent & Cumulative Percent \\
\hline English & 127 & 86.4 & 86.4 & 86.4 \\
\hline Turkish & 20 & 13.6 & 13.6 & 100.0 \\
\hline Total & 147 & 100.0 & 100.0 & \\
\hline & & & & \\
\hline $\begin{array}{l}\text { Do you depend on } \\
\text { translation to } \\
\text { understand English } \\
\text { on social media? }\end{array}$ & Frequency & Percent & Valid Percent & Cumulative Percent \\
\hline Yes & 35 & 23.8 & 23.8 & 23.8 \\
\hline No & 112 & 76.2 & 76.2 & 100.0 \\
\hline Total & 147 & 100.0 & 100.0 & \\
\hline & & & & \\
\hline $\begin{array}{l}\text { Do you depend on } \\
\text { translation to } \\
\text { understand Turkish } \\
\text { on social media? }\end{array}$ & Frequency & Percent & Valid Percent & Cumulative Percent \\
\hline $\begin{array}{l}\text { YES } \\
\text { N0 }\end{array}$ & 110 & 74.8 & 74.8 & 100.0 \\
\hline Total & 37 & 25.2 & 25.2 & \\
\hline & 147 & 100.0 & 100.0 & \\
\hline Source: Field Survey 2017 & & & \\
\hline
\end{tabular}

Source: Field Survey 2017.

On the use of language which was put on Likert scale $(n=31) 21.1 \%$ strongly agreed that they can read media messages in Turkish because they can read and understand Turkish, $(n=21) 14.3 \%$ agree too, $(n=14)$ with $9.5 \%$ are undecided, $(n=44) 29.9 \%$ disagree and $(n=37) 25.2 \%$ strongly disagreed.

Meanwhile in the case of interaction on social media, using Turkish because they don't have problem with the language, $(n=26) 17.7 \%$ strongly agree, $(n=28) 19.0 \%$ agree, undecided $(n=17)$ which stood at $11.6 \%$ while $(n=44) 29.9 \%$ disagree as $(n=37) 25.2 \%$ strongly disagree, this means that respondents strongly disagree with the statement that implies possibility of having problem may be there as on the agree level it is about $19.0 \%$. 
In the case of translation, to know if the respondents need translations to enable them understand a message in Turkish since they don't understand it ordinarily. the results revealed that about $(n=66) 44.9 \%$ strongly agree, $(n=37) 25.2 \%$ agree, undecided respondents recorded $(n=11) 7.5 \%$, respondents who disagree are $(n=20) 13.6 \%$ while those who strongly disagree are $(n=13) 8.8 \%$. Hence, almost half of the respondents indicated interest for translation since ordinarily they may not understand Turkish language.

In the same vein, on whether there is need for translation to understand English, result shows that $(n=19)$ representing $12.9 \%$ strongly agree that they need translation, $(n=21) 14.3 \%$ agree, undecided respondents numbered (13) with $8.8 \%$. While $(n=50)$ representing $34 \%$ disagree and $(n=44) 29.9 \%$ strongly disagree. This implies that there is no much need of translation to help the people understand the English language while using social media in north Cyprus.

Responding to the item "I am Turkish Cypriot but prefer to use English", 15 of the respondents representing $10.2 \%$ strongly agree, $20.4 \%$ agree, 34 of the respondents at $23.1 \%$ are undecided, about 44 of the respondent disagree representing $29.9 \%$. This implies that Turkish Cypriots prefer to use Turkish language on social media rather than English language.

On the item using English because it is accessible on social media 74 of respondents strongly agree representing about $50.3 \%$ of the population size, 49 respondents at $33.3 \%$ agree, while 16 respondents at $10.9 \%$ are undecided, only 2 of the respondents disagree with the view at $1.4 \%$ while $4.1 \%$ of the people representing 6 respondents strongly disagree. This implies that as far as Northern Cyprus is concerned, English language is more accessible on social media against Turkish language as about half of the respondents strongly agree with this assertion.

In the case of writing in Turkish on social media because the respondents are Turkish and Turkish is easier, results reveal that 18 of the respondents strongly agree at about $12.2 \%, 22$ of the respondents at $15.0 \%$ agree with the assertion, 16 respondents at $10.9 \%$ percent are undecided on the matter, 45 of the respondents disagree at $30.6 \%$ and $31.3 \%$ strongly disagree. This shows that being a Turkish Cypriot doesn't guarantee ease in writing Turkish on social media. In other words, they find it easier with English than Turkish even though Turkish is their first language. Table below shows.

\section{Use of language}

TABLE 3

\begin{tabular}{|c|c|c|c|c|}
\hline $\begin{array}{l}\text { I read media } \\
\text { messages in } \\
\text { Turkish because I } \\
\text { can read and } \\
\text { understand Turkish }\end{array}$ & Frequency & Percent & $\begin{array}{l}\text { Valid } \\
\text { Percent }\end{array}$ & $\begin{array}{l}\text { Cumulative } \\
\text { Percent }\end{array}$ \\
\hline strongly agree & 31 & 21.1 & 21.1 & 21.1 \\
\hline Agree & 21 & 14.3 & 14.3 & 35.4 \\
\hline Undecided & 14 & 9.5 & 9.5 & 44.9 \\
\hline Disagree & 44 & 29.9 & 29.9 & 74.8 \\
\hline strongly disagree & 37 & 25.2 & 25.2 & 100.0 \\
\hline Total & 147 & 100.0 & 100.0 & \\
\hline $\begin{array}{l}\text { I interact on social } \\
\text { media using } \\
\text { Turkish because I }\end{array}$ & Frequency & Percent & Valid Percent & $\begin{array}{l}\text { Cumulative } \\
\text { Percent }\end{array}$ \\
\hline
\end{tabular}




\begin{tabular}{|c|c|c|c|c|}
\hline $\begin{array}{l}\text { don't have problem } \\
\text { with the language }\end{array}$ & & & & \\
\hline strongly agree & 26 & 17.7 & 17.7 & 17.7 \\
\hline Agree & 28 & 19.0 & 19.0 & 36.7 \\
\hline Undecided & 17 & 11.6 & 11.6 & 48.3 \\
\hline Disagree & 46 & 31.3 & 31.3 & 79.6 \\
\hline strongly disagree & 30 & 20.4 & 20.4 & 100.0 \\
\hline Total & 147 & 100.0 & 100.0 & \\
\hline $\begin{array}{l}\text { I need translation } \\
\text { to understand } \\
\text { messages in } \\
\text { Turkish because I } \\
\text { don't understand it } \\
\text { ordinarily }\end{array}$ & Frequency & Percent & Valid Percent & $\begin{array}{l}\text { Cumulative } \\
\text { Percent }\end{array}$ \\
\hline strongly agree & 66 & 44.9 & 44.9 & 44.9 \\
\hline Agree & 37 & 25.2 & 25.2 & 70.1 \\
\hline Undecided & 11 & 7.5 & 7.5 & 77.6 \\
\hline Disagree & 20 & 13.6 & 13.6 & 91.2 \\
\hline strongly disagree & 13 & 8.8 & 8.8 & 100.0 \\
\hline Total & 147 & 100.0 & 100.0 & \\
\hline $\begin{array}{l}\text { I need Turkish } \\
\text { translation on } \\
\text { social media } \\
\text { because it is } \\
\text { difficult to } \\
\text { understand } \\
\text { messages in } \\
\text { English }\end{array}$ & Frequency & Percent & Valid Percent & $\begin{array}{l}\text { Cumulative } \\
\text { Percent }\end{array}$ \\
\hline strongly agree & 19 & 12.9 & 12.9 & 12.9 \\
\hline Agree & 21 & 14.3 & 14.3 & 27.2 \\
\hline Undecided & 13 & 8.8 & 8.8 & 36.1 \\
\hline Disagree & 50 & 34.0 & 34.0 & 70.1 \\
\hline strongly disagree & 44 & 29.9 & 29.9 & 100.0 \\
\hline Total & 147 & 100.0 & 100.0 & \\
\hline $\begin{array}{l}\text { I am Turkish but } \\
\text { prefer to use } \\
\text { English on social } \\
\text { media }\end{array}$ & Frequency & Percent & Valid Percent & $\begin{array}{l}\text { Cumulative } \\
\text { Percent }\end{array}$ \\
\hline strongly agree & 15 & 10.2 & 10.2 & 10.2 \\
\hline Agree & 30 & 20.4 & 20.4 & 30.6 \\
\hline Undecided & 24 & 16.3 & 16.3 & 46.9 \\
\hline Disagree & 34 & 23.1 & 23.1 & 70.1 \\
\hline strongly disagree & 44 & 29.9 & 29.9 & 100.0 \\
\hline Total & 147 & 100.0 & 100.0 & \\
\hline $\begin{array}{l}\text { I use English } \\
\text { because it is } \\
\text { accessible for me } \\
\text { on social media }\end{array}$ & Frequency & Percent & Valid Percent & $\begin{array}{l}\text { Cumulative } \\
\text { Percent }\end{array}$ \\
\hline
\end{tabular}




\begin{tabular}{|c|c|c|c|c|}
\hline strongly agree & 74 & 50.3 & 50.3 & 50.3 \\
\hline Agree & 49 & 33.3 & 33.3 & 83.7 \\
\hline Undecided & 16 & 10.9 & 10.9 & 94.6 \\
\hline Disagree & 2 & 1.4 & 1.4 & 95.9 \\
\hline strongly disagree & 6 & 4.1 & 4.1 & 100.0 \\
\hline Total & 147 & 100.0 & 100.0 & \\
\hline $\begin{array}{l}\text { I write in Turkish } \\
\text { on social media } \\
\text { because I am } \\
\text { Turkish and it is } \\
\text { easier }\end{array}$ & Frequency & Percent & Valid Percent & $\begin{array}{l}\text { Cumulative } \\
\text { Percent }\end{array}$ \\
\hline strongly agree & 18 & 12.2 & 12.2 & 12.2 \\
\hline Agree & 22 & 15.0 & 15.0 & 27.2 \\
\hline Undecided & 16 & 10.9 & 10.9 & 38.1 \\
\hline Disagree & 45 & 30.6 & 30.6 & 68.7 \\
\hline strongly disagree & 46 & 31.3 & 31.3 & 100.0 \\
\hline Total & 147 & 100.0 & 100.0 & \\
\hline
\end{tabular}

Source: Field Survey 2017.

In the perception section of the study on "if respondents feel comfortable when they write in English on social media platforms because it is widely spoken across the globe" About 103 of the respondents strongly agree with about $70.1 \%, 32$ of the participants also agree with about $21.8 \%, 4$ respondents are undecided at $2.7 \%, 7$ of the respondents disagree giving $4.8 \%$ and 1 respondent strongly disagree with $0.7 \%$. This shows that more than half of the people feel very comfortable when they use the English language, with insignificant percentage of less than 1strongly disagreeing.

On issue of whether they feel comfortable using Turkish on social media since it is not spoken by all, about 33 of the respondents strongly agree with the statement, 49 agree at $22.4 \%$ and $33.3 \%$ respectively, about 29 of the respondents disagree at $19.7 \%, 29$ of the respondents with $19.7 \%$ are undecided, while 12 of the respondents strongly disagree at $8.2 \%$.

Finding out to know if respondents think Turkish language on social media is restricted and limited to only Turks and Turkish Cypriots, $22.4 \%$ of the respondents numbering 33 strongly agree, 49 of the respondents representing $33.3 \%$ agree, 13 are undecided with $8.8 \%, 30$ of the respondents disagree at $20.4 \%$, while 22 respondents strongly disagree at about $15.0 \%$. This implies that about 44 of the respondents agree that the use of Turkish may be restricted to Turkish speakers only. See the table below

\section{Perception of English and Turkish on social media}

TABLE 4

\begin{tabular}{|l|l|l|l|l|}
\hline $\begin{array}{l}\text { I feel } \\
\text { comfortable } \\
\text { when I write } \\
\text { English on } \\
\text { Social media } \\
\text { because it's } \\
\text { widely spoken } \\
\text { across the } \\
\text { globe }\end{array}$ & & & \\
\hline Strongly agree & 93 & & \\
Frequency & Percent & $\begin{array}{l}\text { Valid } \\
\text { Percent }\end{array}$ & $\begin{array}{l}\text { Cumulative } \\
\text { Percent }\end{array}$ \\
\hline
\end{tabular}




\begin{tabular}{|c|c|c|c|c|}
\hline Agree & 32 & 21.8 & 21.8 & 91.8 \\
\hline Undecided & 4 & 2.7 & 2.7 & 94.6 \\
\hline Disagree & 7 & 4.8 & 4.8 & 99.3 \\
\hline strongly disagree & 1 & .7 & .7 & 100.0 \\
\hline Total & 147 & 100.0 & 100.0 & \\
\hline \multicolumn{3}{|c|}{$\begin{array}{l}\text { I don't feel comfortable when I use Turkish } \\
\text { On social media beEacusent's not spolkendeytall }\end{array}$} & $\begin{array}{l}\text { Valid } \\
\text { Percent }\end{array}$ & $\begin{array}{l}\text { Cumulative } \\
\text { Percent }\end{array}$ \\
\hline strongly agree & 33 & 22.4 & 22.4 & 22.4 \\
\hline Agree & 44 & 29.9 & 29.9 & 52.4 \\
\hline Undecided & 29 & 19.7 & 19.7 & 72.1 \\
\hline Disagree & 29 & 19.7 & 19.7 & 91.8 \\
\hline strongly disagree & 12 & 8.2 & 8.2 & 100.0 \\
\hline Total & 147 & 100.0 & 100.0 & \\
\hline $\begin{array}{l}\text { I think using } \\
\text { Turkish } \\
\text { language on } \\
\text { social media is } \\
\text { restricted and } \\
\text { limited to only } \\
\text { Turks and } \\
\text { Turkish } \\
\text { Cypriots. }\end{array}$ & Frequency & Percent & $\begin{array}{l}\text { Valid } \\
\text { Percent }\end{array}$ & $\begin{array}{l}\text { Cumulative } \\
\text { Percent }\end{array}$ \\
\hline strongly agree & 33 & 22.4 & 22.4 & 22.4 \\
\hline Agree & 49 & 33.3 & 33.3 & 55.8 \\
\hline Undecided & 13 & 8.8 & 8.8 & 64.6 \\
\hline Disagree & 30 & 20.4 & 20.4 & 85.0 \\
\hline strongly disagree & 22 & 15.0 & 15.0 & 100.0 \\
\hline Total & 147 & 100.0 & 100.0 & \\
\hline
\end{tabular}

Source: Field Survey 2017.

\section{Results}

From the study, results show that social media is used on daily basis among people living in North Cyprus. Table 1 reveals that the highest numbers of social media users in North Cyprus aremales and undergraduate students within the ages of 18-25. From table 2 , we realize that out of the 147 respondents, only 23 are citizens of North Cyprus while 124 are non-citizens in other words, the academic environment is dominated more by foreigners than indigenes who are Turkish Cypriots. We also see in table 2, that people who use social media for communication constitute 144 out of 147 respondents whereas just 3 aren't users of social media. still on table 2, result reveals that among the social media users, people spend majorly from 1-3 hours out of 24 hours daily on social media.

The same table also shows that out of 147 respondents, 52 agree to use Turkish for written communication on social media while 95 oppose to it. This implies that irrespective of Turkish being the language of the immediate environment, it is not applicable on social media in the same environment. As well, whereas 49 affirm to understanding Turkish messages, adverts and news on social media, 98 respondents are on the negative. Also, as to understanding and responding to spoken Turkish on social media, 52 respondents agree to it while 95 are on the negative stand. Incidentally, on the same table 2, the item as to which language is commonly used on social media between English and Turkish, about 127 respondents ticked English while 20 ticked 
Turkish.

Dependence on translation to understand English on social media, 35 respondents agree that they depend on translation, while 112 don't thus implying that more people within North Cyprus are conversant with English on social media than not. On translation to understand Turkish language, result shows that 110 out of 147 respondents depend on translation to understand Turkish language on social media which means Turkish language is not commonly used among social media users in North Cyprus. In table 3, the first item as to whether media messages are read in Turkish because respondents can read and understand Turkish, 31 strongly agree while37 strongly disagree, 21 agree and 37 disagree. Even though 14 respondents are undecided, the result signifies that the negatives are more implying that ability to read and understand Turkish doesn't guarantee same on social media. the second item on table 3 as to whether social media users interact on social media using Turkish because they don't have problem with the language , 26 strongly agree, 28 agree, 30 strongly disagree while 46 disagree leaving 17 respondents undecided. This means that the negatives are higher again, implying that social media users in North Cyprus who interact in Turkish on social media platforms don't necessarily do so because they don't have a problem with the language.

On people who need translation to understand messages in Turkish because they don't understand it ordinarily, result on table 3 shows that out of 147 respondents, 66 strongly agree, 13 strongly disagree meaning that some people need translation to understand Turkish on social media because they don't ordinarily understand Turkish language.

On whether respondents need Turkish translation on social media because it is difficult to understand messages in English, 19 strongly agree while 44 strongly disagree in other words fewer people in North Cyprus consider English difficult to use on social media. As for Turkish Cypriots who prefer to use English on social media, 15 respondents strongly agree to the assertion while 44 strongly disagree.Disagree34, while 24 are undecided about it. In other words, in Northern Cyprus, citizens prefer to use their first language being Turkish on social media rather than English.

For people who use English because it is accessible for them on social media, 74 respondents strongly agree to it while a small fraction of 6 strongly disagree showing that in North Cyprus, English is commonly accessible to a wide range of social media users. As to whether people write in Turkish on social media because they are Turkish and it is easier for them, 18 respondents strongly agree while 46 strongly disagree which means that most people who write in Turkish on social media do so not just because they are Turkish and it is easier for them but for some other unidentified reasons.

On table 4, the first item as to whether they feel comfortable when they write in English on social media because it is widely spoken across the globe, 103 respondents were positive on the take while 1 respondent was on the negative perception.

Out of 147, the few who disagree, strongly disagree and undecided are near insignificant as compared to the number who strongly agree and agree implying that English being spoken globally is a factor influencing its usage by social media users in North Cyprus. Still on table 4, the item as to whether people don't feel comfortable when they use Turkish on social media because it is not widely spoken, 33 respondents strongly affirm, 44 agree to it whereas 12 strongly disagree, 29 disagree totally the sum off 77 for the affirmative respondents and 41 for those who oppose it. Hence, implying that more social media users in North Cyprus don't feel comfortable using Turkish on social media platforms because it is not widely spoken. Finally, about if people think that using Turkish on social media is limited to Turks and Northern Cypriots, result shows that 33 respondents strongly think so, 49 agree whereas 30 strongly disagree 
and 22 disagree. Hence, the affirmative respondents are more implying that more people using social media in North Cyprus think that Turkish language on social media is limited to Turks and Northern Cypriots.

\section{Conclusion}

With the results and findings obtained in this study, and in answer to the research questions, it has been revealed and therefore concludes that as far as social media in North Cyprus is concerned, majority of social media users don't need translation aid to understand and use English language rather, so many people depend on translation aids to understand messages in Turkish language on social media platforms. Also, in number of usage and convenience, the study shows that above $80 \%$ of social media users in North Cyprus adopt English as the active language used on social media, while just a small proportion of less than $15 \%$ adopt and use Turkish language for social media activities. Hence, irrespective of Turkish being the language of the Northern Cyprus environment, English language which is rather a second language has dominated and overshadowed Turkish in terms of social media use and activities.

\section{References}

Awake. (2012, February). Awake. What should you know about Social Networking, pp. 3-9.

boyd, O., \& Ellison, B. (2007). Social Networking Sites: Definition of History and Scholarship. J pournal of ComputerMediated Communication, 210-230 13(1).

Cogo, A. (2008). English as a lingual Franca. Forms follow functions. English Today, 58$61(24) 3$.

Courtney, N. (2007). Library 2.0 and Beyond: Innovative Technologies and Tomorrow's User. West port llibraries unlimited.

Crystal, D. (1997). English as a global language. New York: Cambridge university press.

Ebere, O. C., \& Oghenetega, L. U. (2014). The impact of Social Media on the Academic Performance of University Students in Nigeria. Journal of Education and Practice, 21-24.

Hamel, R. E. (1997). Introduction: Linguistic human rights in a sociolinguistic perspective.

Hornby, A. P. (1980). Achieving Second Language Fluency through Immersion Education. Foreign Language Annal, 107-113.

Kangas, S. (1996). Language and self-determination on self determination. United Kingdom: Palgrave Macmillan.

Leech, N., \& Short, M. (2007). Style in Fiction.A linguistic Introduction to English Fiction and Prose. New York: Rouledge.

Menghinin, M. (2017). Supporting Multilingualism in academic writing. International journal of language studies, 107-130 vol 11(4).

Naurt, R. (2007, september 03). College student addicted to social media study finds. Retrieved September 03, 2017, from Livescience.http/wwwlivescience.com.

Necatigil, Z. M. (1993). The Cyprus Question AND the Turkish Position in International Law. New York: Oxford University press.

Oghenetega, L. U., \& Ejedafiru, E. F. (2014). Librarians and Social Media as Catalyst for national development in Nigeria (forthcoming). Library Philosophy and Practice(ejournal).

Ohiagu, O., \& Okorie, O. (2014). Social Media: Shaping and Transmitting Popular Culture. Covenant J ournal of Communication, 93-107 12(1).

Smokotin, V. M., Alekeseyenko, A. S., \& Petrova, G. L. (2014). The phenomenon of linguistic Globalization: English s the Global Lingua Franca (EGLF). Procedia-Social Behavioural Sciences, 509-513.

Turner, L. (2015). Turkey, Central Asia and South Caucus. Istanbul: Neal.

Young, K. S. (1998). Internet Addiction: The emergence of a new Clinical Disorder. Cyberpsychology and Behaviour, 237-244 1(3). 